\title{
The antimicrobial activity of two phenolic acids against foodborne Escherichia coli and Listeria monocytogenes and their effectiveness in a meat system
}

\author{
Oluwatosin Ademola Ijabadeniyi ${ }^{\text {a*, }}$, Austin Govendera ${ }^{\mathrm{a}}$ Omotola Folake Olagunjua ${ }^{\mathrm{a}}$ Ajibola Bamikole Oyedeji ${ }^{\text {b* }}$ \\ ${ }^{a}$ Department of Biotechnology and Food Technology, Durban University of Technology, Durban, South Africa; ${ }^{b}$ Department \\ of Biotechnology and Food Technology, Faculty of Science, University of Johannesburg, Gauteng, South Africa
}

*Corresponding Authors: Oluwatosin Ademola Ijabadeniyi, Department of Biotechnology and Food Technology, Durban University of Technology, S9 Level 1, Steve Biko Campus, Durban 4000, South Africa. Email: oluwatosini@dut. ac.za; Ajibola Bamikole Oyedeji, Department of Biotechnology and Food Technology, Faculty of Science, University of Johannesburg Doornfontein Campus, P.O. Box: 17011, Gauteng 2028, South Africa. Email: jibanky2@gmail.com

Received: 21 July 2020; Accepted after revision: 14 December 2020; Published: 1 February 2021.

(c) 2021 Codon Publications

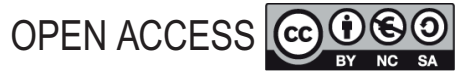

PAPER

\begin{abstract}
Ready-to-eat meats are susceptible to pathogenic contamination during their production, distribution, and sale. This study evaluated the antimicrobial effects of two phenolic acids (caffeic and ferulic acids) against foodborne pathogens in cold-cut meat at low-temperature conditions. The individual and combined antibacterial activities of caffeic and ferulic acids against Escherichia coli O157:H7 ATCC 43888 and Listeria monocytogenes ATCC 7644 were determined by diffusion disk assay in broth media and cold-cut meat. Broth media and meat samples already inoculated with $E$. coli and L. monocytogenes were treated with caffeic acid, ferulic acid, and their combination at the concentrations of $150 \mathrm{ppm}$ and $200 \mathrm{ppm}$ and stored at $4^{\circ} \mathrm{C}$. Microbial growths were monitored at $0,24,48$, and $72 \mathrm{~h}$. Caffeic acid at $200 \mathrm{ppm}$ exhibited a zone of inhibition of $12.33 \mathrm{~mm}$ on E. coli, and ferulic acid revealed a zone of inhibition of $11.00 \mathrm{~mm}$ on L. monocytogenes. The combination of caffeic-ferulic acid at a concentration of 200 ppm was most effective against $E$. coli, demonstrating a synergistic effect over $72 \mathrm{~h}$ at $4^{\circ} \mathrm{C}$ in both broth media and meat. For meat samples, the combination of caffeic acid and ferulic acid exhibited a log reduction of $3.63 \mathrm{CFU} / \mathrm{g}$ at $150 \mathrm{ppm}$ and 2.51 CFU/g at $200 \mathrm{ppm}$ against E. coli O157:H7 at the end of cold storage. Caffeic acid alone exhibited an overall log reduction of $2.48 \mathrm{CFU} / \mathrm{g}$ at $150 \mathrm{ppm}$ and $2.75 \mathrm{CFU} / \mathrm{g}$ at $200 \mathrm{ppm}$ against L. monocytogenes. These results indicate the ability of caffeic and ferulic acids, individually and in combination, to reduce pathogenic contamination and improve safety of cold-cut meats.
\end{abstract}

Keywords: antibacterial activity; caffeic acid; ferulic acid; cold-cut meat; E. coli; L. monocytogenes

\section{Introduction}

Cold-cut meat products such as ham are one of the most commonly consumed ready-to-eat products. They are often in sliced forms and used as fillings for sandwiches and similar foods. They are manufactured from raw pork and/or beef and characterized by physical and biochemical changes that occur during curing (Marušić et al., 2014). In most modern cold-cut meats, nitrites (either sodium nitrite or potassium nitrite) are employed during curing to prevent bacterial growth and survival and enhance safety and storage stability. However, owing to the toxicity of nitrites, some country regulations specify maximum allowable contents in the final product (Campion et al., 2017). This indulges public health concern because, under certain conditions, nitrites in meat can react with degradation products of amino acids, forming nitrosamines, which are known carcinogens 
(Shpazier et al., 2018). Furthermore, foodborne pathogenic bacteria may persist and replicate in cold-cut meats due to their low effective doses, antimicrobial resistance, and capability of adapting to stress conditions without observable sensorial changes in the product (Rybarczyk et al., 2017).

Listeria monocytogenes (L. monocytogenes) is a Grampositive bacterium that thrives in water, soil, and foods (Chen et al., 2017). It is the causative organism for listeriosis and has the potential to contaminate different forms of foods, including low-moisture foods, at different stages within the food chain. It has been implicated in many foodborne disease outbreaks, and some of the most common vehicles involved in these outbreaks include readyto-eat meals, unpasteurized milk, dairy products, meat, fruits, and vegetables (Pernin et al., 2019). Ingestion of foods contaminated with $L$. monocytogenes could result in different symptoms from mild gastroenteritis to severe central nervous system infections. High-risk individuals prone to L. monocytogenes infection include pregnant women and immunocompromised people (Hunjak et al., 2019). Escherichia coli (E. coli) is also a Gram-negative, rod-shaped, ubiquitous bacterium, which also lives in the gut of humans and suppresses the growth of harmful bacteria (Saxena et al., 2015). One of its pathogenic strains, E. coli O157:H7, is listed by the United States Centers for Disease Control (CDC) as a pathogen that has attracted increasing attention due to the number of victims who had to be hospitalized following its ingestion (De Souza et al., 2018). The CDC estimated that in the US, there were 10,000 illnesses, thousands of hospitalizations, and hundreds of deaths attributed to the E. coli O157:H7 yearly. Most E. coli O157:H7 outbreaks are associated with fecal-oral transmission due to poor hygiene and food handling practices. Sources of human infection include poorly cooked meat, apple juice, water, and milk products such as yogurt and unpasteurized milk. These bacteria have been adjudged the most threatening foodborne pathogens because of their severe debilitating effects on humans upon ingestion (Buchanan et al., 2017).

Although various measures have been implemented in the past to control and reduce the prevalence of $L$. monocytogenes and E. coli O157:H7, reports of foodborne disease outbreaks as a result of their infection subsists. Chemical preservatives are capable of inhibiting or inactivating bacterial growth in foods. However, the use of natural preservatives is currently encouraged due to increasing bacterial resistance to chemical preservatives, food safety regulations, and increased awareness of the adverse effects of chemicals (Pernin et al., 2019). Phenolic compounds have attracted much interest due to their antioxidant potential and antimicrobial properties. Phenolic compounds are secondary metabolites produced by plants and can be classified into three different groups based on their chemical structures. These classes include non-flavonoids, flavonoids, and tannins in their simple or complex forms (Pernin et al., 2018). In plant-based foods, phenolic compounds are responsible for the color of red fruits, juices, and wines, substrates involved in enzymatic browning and are also considered to contribute to the health benefits associated with dietary consumption of fruits and vegetables (Cheynier, 2012).

In particular, caffeic and ferulic acids possess aromatic rings with a hydroxyl group $(-\mathrm{OH})$ on the fifth position of their rings while their difference is in the presence of methoxy group $\left(-\mathrm{H}_{3} \mathrm{CO}\right)$ for ferulic acid and hydroxyl group $(-\mathrm{OH})$ at the sixth position of aromatic rings (Sanchez-Maldonado et al., 2011). They are well distributed in plants, and they possess antioxidant and prooxidant properties (Nystrom et al., 2005) substantiated by their functions in the reduction of auto-oxidation by acting as radical scavengers, inhibitors of lipid peroxidation, and low-density lipoproteins (Maurya \& Devasagayam, 2010). Their antioxidant and prooxidant abilities in foods have been adduced to factors such as concentration, chemical structure, and the nature of substrates or foods (Maurya \& Devasagayam, 2010).

Previous studies have validated the antimicrobial properties of phenolic compounds against bacteria, including pathogenic species. These findings justified that their use could be an alternative means of inhibiting or inactivating the growth of L. monocytogenes and E. coli (Vaquero et al., 2007). When combined, phenolic acids could reflect greater antimicrobial efficacy against foodborne pathogens, compared to individual phenolic acids. Therefore, this study was conducted to investigate the individual and combined antimicrobial effects of caffeic and ferulic acids on the survival of L. monocytogenes ATCC 7644 and E. coli O157:H7 ATCC 43888 in cold-cut meat products under low-temperature storage conditions.

\section{Materials and Methods}

\section{Preparation of inoculum}

The bacterial strains L. monocytogenes ATCC 7644 and E. coli O157:H7 ATCC were obtained from the microbial culture collection of the Department of Biotechnology and Food Technology, Durban University of Technology. Stock cultures of L. monocytogenes were grown aerobically for $24 \mathrm{~h}$ at $30^{\circ} \mathrm{C}$ in brain heart infusion (BHI) broth. For E. coli, stock cultures were grown at $37^{\circ} \mathrm{C}$ for $24 \mathrm{~h}$ in tryptic soy broth (TSB). A loopful of the stock culture of each microorganism was transferred to $10 \mathrm{~mL}$ of $\mathrm{BHI}$ and TSB, as applicable, and incubated at $37^{\circ} \mathrm{C}$ for 
24 h. Turbidity of cultures was adjusted to match that of a $0.5 \mathrm{McF}$ arland standard to achieve an approximate $10^{8} \mathrm{CFU} / \mathrm{mL}$ in each case.

\section{Preparation of phenolic acid extracts}

Caffeic acid and ferulic acid ( $>98 \%$ purity) were purchased from Sigma-Aldrich (Johannesburg, South Africa). To elucidate the antimicrobial properties, these phenolic compounds were dissolved in $99.8 \%$ ethanol (Merck, Johannesburg, South Africa). However, for broth and meat experiments, the phenolic acids were dissolved in water at $1 \% \mathrm{w} / \mathrm{v}$ (Zhang et al., 2016). The solutions were filtered through $0.22-\mu \mathrm{m}$ membrane filters in each case and stored at $4^{\circ} \mathrm{C}$ in sterilized glass containers until needed.

\section{Antibacterial activity determination}

For agar disk diffusion assay, $0.1 \mathrm{~mL}$ of each bacterial culture suspension was transferred into Petri dishes containing Mueller Hinton agar (Merck, Johannesburg, South Africa) and were uniformly spread onto the surface with the help of a sterile plate spreader. Fifty microliters of phenolic acids solutions, at different concentrations (150 and $200 \mathrm{ppm}$ ), were pipetted on $6 \mathrm{~mm}$ sterile filter paper disks (Whatman No. 1) and air-dried in a laminar flow chamber. Distilled water was used as the negative control, while Ciprofloxacin (Merck, Johannesburg, South Africa) was used as the positive control for its effectiveness against both Gram-positive and Gram-negative bacteria. These dried disks were then transferred into inoculated plates and incubated at $30^{\circ} \mathrm{C}$ for $24 \mathrm{~h}$ for L.monocytogenes and $37^{\circ} \mathrm{C}$ for E. coli. Antibacterial activity for each phenolic acid and their combination was determined by measuring the inhibition zone around the disk following a 24-hour incubation period. Each experiment was replicated at least three times.

\section{Broth study}

In each case, $1 \mathrm{~mL}$ bacterial suspension containing $1 \times 10^{8}$ $\mathrm{CFU} / \mathrm{mL}$ E. coli and L. monocytogenes were transferred into either BHI broth for L. monocytogenes or TSB broth for E. coli O157:H7. Thereafter, $50 \mu \mathrm{L}$ of individual solutions of caffeic and ferulic acid of $150 \mathrm{ppm}$ and $200 \mathrm{ppm}$ concentration as well as a combination (1:1) of caffeic and ferulic acid solutions (150 ppm:75 ppm of each and 200 ppm:100 ppm of each) were added to inoculated broths. An inoculum containing a bacterial suspension of $1 \times 10^{8}$ $\mathrm{CFU} / \mathrm{mL}$ of each bacterium that was not treated by the phenolic acids served as the control samples. The samples were then stored at $4^{\circ} \mathrm{C}$ for $72 \mathrm{~h}$. Microbial survival in each broth treatment was determined at $12,24,48$, and $72 \mathrm{~h}$ by pour-plating six serial dilutions on appropriate growth agar. Plates were incubated at $37^{\circ} \mathrm{C}$ for $24 \mathrm{~h}$ before enumeration. Each experiment was repeated at least thrice.

\section{Meat study}

Cold-cut meat samples were bought from a trusted retail outlet and sliced into $5 \mathrm{~g}$ portions. For sterilization, the samples were dipped into 95\% ethanol solution and left to dry in a laminar flow chamber. Afterward, $0.1 \mathrm{~mL}$ of each bacterial suspension was spot-inoculated onto the meat samples and spread out onto the surface of the meat using sterile spreader. Inoculated meat samples were then dried for $1 \mathrm{~h}$ at room temperature. Thereafter, samples were dipped in phenolic acid solutions containing a concentration of $150 \mathrm{ppm}$ and $200 \mathrm{ppm}$ of each phenolic acid and their combination (1:1) for $60 \mathrm{~s}$. Broth inoculum containing a bacterial suspension of $1 \times 10^{8} \mathrm{CFU} / \mathrm{mL}$ for each strain was used as the control. The samples were stored at $4^{\circ} \mathrm{C}$ for a 72 -hour period in sterilized stomacher bags containing phosphate buffer solution (PBS). Microbial survival was also evaluated at $12,24,48$, and $72 \mathrm{~h}$. Plates were incubated at $37^{\circ} \mathrm{C}$ for $24 \mathrm{~h}$ prior to enumeration. Each experiment was repeated at least three times.

\section{Statistical analysis}

All experiments were performed in triplicate. Experimental data were analyzed by ANOVA (Analysis of Variance) $(\mathrm{P}<0.05)$. The mean values of the experimental growth data were compared using Duncan's multiple range test.

\section{Results and Discussion}

\section{Antibacterial activity of phenolic acids using disk diffusion assay}

The effects of caffeic acid, ferulic acid, and their combination on the growth of L. monocytogenes and E. coli O157:H7 are shown in Table 1. They demonstrated various degrees of inhibition against the two pathogenic strains. Ferulic acid was found to be most effective against the E. coli $\mathrm{O} 157: \mathrm{H} 7$ strain at $150 \mathrm{ppm}$ concentration, with a zone of inhibition of $10 \mathrm{~mm}$, compared to caffeic acid and their combination at the same concentration. There was no difference $(\mathrm{P}<0.05)$ in the inhibitory actions of caffeic acid and the combination of caffeic and ferulic acids at this same concentration (150 ppm). With an increase in the ferulic acid concentration to $200 \mathrm{ppm}$, the zone of 
inhibition was found to increase further. For L. monocytogenes, caffeic acid was the most effective antibacterial agent at the two concentrations tested, giving zones of inhibition of 7.66 and $11 \mathrm{~mm}$ at 150 and $200 \mathrm{ppm}$, respectively. The structure-function relationships between the antimicrobials and the respective microorganisms could justify the contrasting activities of the phenolic acids against Gram-positive and Gram-negative bacteria (Sánchez-Maldonado et al., 2011). Distilled water did not inhibit the growth of organisms as no inhibition zones was detected during screening. Ciprofloxacin, used as the positive control, demonstrated greater inhibitory potential for L. monocytogenes, possibly due to differences in the cell wall structures of Gram-positive and Gram-negative bacteria. The combination of caffeic acid and ferulic acid exhibited a joint effect at both concentrations, suggesting an affinity relationship between the two antimicrobials. However, they tend to possess a greater antimicrobial activity individually than in combination.

\section{Inhibitory effect of phenolic acids against $E$. coli 0157:H7 and L. monocytogenes in broth}

The growth response of E. coli O157:H7 and L. monocytogenes in broth media treated with phenolic acids at 150 or $200 \mathrm{ppm}$ and stored at $4^{\circ} \mathrm{C}$ for a $72 \mathrm{~h}$ period is presented in Table 2 . The high levels of $L$. monocytogenes and $E$. coli inocula in broth and meat samples in this study are necessary to clearly understand the efficiency of the different concentrations of phenolic acids and the extent of their activity in highly contaminated food materials. Inoculum levels excess of $10^{7}-10^{9}$ have been used by previous authors (De Souza et al., 2018; Kwon et al., 2019; Rodriguez-Vaquero et al., 2007). In the control medium, the number of viable cells of $E$. coli $\mathrm{O} 157: \mathrm{H} 7$ increased from $7.70 \times 10^{8}$ to $8.01 \times 10^{8} \mathrm{CFU} / \mathrm{mL}$ at the end of the incubation period (72 h). For L. monocytogenes, the number of viable cells in the control medium increased from
$7.87 \times 10^{8}$ after $12 \mathrm{~h}$ to $8.21 \times 10^{8}$ at the end of the incubation period. At a concentration of $150 \mathrm{ppm}$, ferulic acid was the most effective antimicrobial agent against $E$. coli O157:H7, showing a reduction of $2.98 \log \mathrm{CFU} / \mathrm{mL}$, while caffeic acid was the most effective against $L$. monocytogenes with a $\log$ reduction of $2.17 \log \mathrm{CFU} / \mathrm{mL}$ following the incubation period. The combination of caffeic acid and ferulic acid in a 1:1 ratio demonstrated a synergistic effect whereby the viability of microorganisms diminished by 2.42 and $2.14 \log$ cycles, respectively. At a concentration of $200 \mathrm{ppm}$, the order of effectiveness remained the same for both Gram-positive and Gram-negative strains; however, a higher inhibition rate was observed (Table 2) a reduction of $3.49 \log \mathrm{CFU} / \mathrm{mL}$ against E. coli $\mathrm{O} 157: \mathrm{H} 7$ by ferulic acid and $2.35 \log \mathrm{CFU} / \mathrm{mL}$ against $L$. monocytogenes by caffeic acid. The synergistic effect of the combination of caffeic acid and ferulic acid enhanced the reduction of viability of microorganisms by 2.42 and 2.25 $\log \mathrm{CFU} / \mathrm{mL}$ (at $150 \mathrm{ppm}$ ) as well as 3.14 and $2.62 \mathrm{log}$ $\mathrm{CFU} / \mathrm{mL}$ for $E$. coli and L. monocytogenes, respectively. In a previous study, the combination of caffeic acid and gallic acid, at $100 \mathrm{ppm}$ and $200 \mathrm{ppm}$ solution produced 1 $\log \mathrm{CFU} / \mathrm{mL}$ and $2 \log \mathrm{CFU} / \mathrm{mL}$ reduction of $L$. monocytogenes, respectively, in meat (Rodriguez-Vaquero et al., 2011). In broth media, phenolic acids were less effective against L. monocytogenes. A possible explanation could be that the microorganism can proliferate under refrigeration conditions, allowing it to be more adaptable to the stress imposed by phenolic acids.

\section{Inhibitory effect of phenolic acids against $E$. coli 0157:H7 and $L$. monocytogenes in cold-cut meats}

Table 3 illustrates the growth response of E. coli O157:H7 and L. monocytogenes in cold-cut meats treated with phenolic acids and stored at $4^{\circ} \mathrm{C}$ for over $72 \mathrm{~h}$. The number of viable cells in the control samples increased from $7.49 \times 10^{8}$ to $7.75 \times 10^{8} \mathrm{CFU} / \mathrm{mL}$ for E. coli $\mathrm{O} 157: \mathrm{H} 7$ and

Table 1. Antibacterial activity of phenolic compounds against E. coli 0157:H7 and L. monocytogenes determined by disk diffusion assay.

\begin{tabular}{|c|c|c|c|}
\hline \multirow[t]{2}{*}{ Treatments } & \multirow[t]{2}{*}{ Concentration } & \multicolumn{2}{|c|}{ Zone of inhibition (mm) Organism } \\
\hline & & E. coli 0157:H7 (ATCC 43888) & L. monocytogenes (ATCC 7644) \\
\hline \multirow[t]{2}{*}{ Caffeic acid } & 150 ppm & $7.00 \pm 1.73^{b}$ & $7.66 \pm 2.51^{b}$ \\
\hline & 200 ppm & $9.33 \pm 1.15^{\mathrm{a}}$ & $11.00 \pm 3.00^{\mathrm{a}}$ \\
\hline \multirow[t]{2}{*}{ Ferulic acid } & 150 ppm & $10.00 \pm 2.00^{b}$ & $6.00 \pm 1.72^{b}$ \\
\hline & 200 ppm & $12.33 \pm 2.51^{\mathrm{a}}$ & $8.33 \pm 2.52^{\mathrm{a}}$ \\
\hline \multirow[t]{2}{*}{ Combination (1:1) } & 150 ppm & $7.00 \pm 1.73^{b}$ & $6.67 \pm 1.15^{\mathrm{b}}$ \\
\hline & 200 ppm & $8.67 \pm 1.16^{a}$ & $7.66 \pm 2.51^{\mathrm{a}}$ \\
\hline \multirow[t]{2}{*}{ Control } & Positive & $26.67 \pm 2.88^{a}$ & $36.67 \pm 2.89^{a}$ \\
\hline & Negative & ND & ND \\
\hline
\end{tabular}

Superscripts indicate significant differences $(P<0.05)$ across the columns only for each phenolic acid and concentration. 
Table 2 The effect of phenolic compounds (at $150 \mathrm{ppm}$ and $200 \mathrm{ppm}$ ) against $\mathrm{E}$. coli 0157:H7 and L. monocytogenes at $4^{\circ} \mathrm{C}$ for over $72 \mathrm{~h}$ in a broth medium.

\begin{tabular}{|c|c|c|c|c|}
\hline \multirow[t]{2}{*}{ Phenolic acids (150 ppm) } & \multicolumn{4}{|c|}{ Population (log CFU/mL) over storage period $(\mathrm{h})$ of } \\
\hline & 12 & 24 & 48 & 72 \\
\hline \multicolumn{5}{|l|}{ E. coli 0157:H7 (ATCC 43888) } \\
\hline Control & $7.70 \pm 0.04^{\mathrm{a}}$ & $7.80 \pm 0.04^{\mathrm{a}}$ & $7.92 \pm 0.06^{\mathrm{a}}$ & $8.01 \pm 0.04^{\mathrm{a}}$ \\
\hline Caffeic acid & $6.08 \pm 0.07^{b}$ & $5.73 \pm 0.05^{\mathrm{b}}$ & $5.71 \pm 0.05^{\mathrm{b}}$ & $5.63 \pm 0.06^{b}$ \\
\hline Ferulic acid & $5.89 \pm 0.03^{c}$ & $5.57 \pm 0.03^{b}$ & $5.55 \pm 0.05^{b}$ & $5.03 \pm 0.05^{b}$ \\
\hline Combination (1:1) & $6.01 \pm 0.03^{b}$ & $5.70 \pm 0.13^{b}$ & $5.61 \pm 0.03^{b}$ & $5.59 \pm 0.07 b$ \\
\hline \multicolumn{5}{|c|}{ L. monocytogenes (ATCC 7644) } \\
\hline Control & $7.87 \pm 0.03^{\mathrm{a}}$ & $8.08 \pm 0.05^{\mathrm{a}}$ & $8.17 \pm 0.04^{\mathrm{a}}$ & $8.21 \pm 0.03^{a}$ \\
\hline Caffeic acid & $6.24 \pm 0.02^{b}$ & $6.13 \pm 0.02^{b}$ & $6.08 \pm 0.03^{b}$ & $6.04 \pm 0.05^{b}$ \\
\hline Ferulic acid & $6.36 \pm 0.03^{b}$ & $6.18 \pm 0.02^{b}$ & $6.14 \pm 0.03^{b}$ & $6.11 \pm 0.03^{b}$ \\
\hline Combination (1:1) & $6.33 \pm 0.03^{b}$ & $6.18 \pm 0.03^{b}$ & $6.12 \pm 0.02^{b}$ & $6.07 \pm 0.04^{b}$ \\
\hline \multicolumn{5}{|c|}{$\begin{array}{l}\text { Phenolic acids (200 ppm) } \\
\text { E. coli 0157:H7 (ATCC 43888) }\end{array}$} \\
\hline Control & $7.70 \pm 0.04^{\mathrm{a}}$ & $7.80 \pm 0.04^{\mathrm{a}}$ & $7.92 \pm 0.06^{\mathrm{a}}$ & $8.01 \pm 0.04^{a}$ \\
\hline Caffeic acid & $6.30 \pm 0.02^{b}$ & $6.27 \pm 0.02^{b}$ & $5.34 \pm 0.01^{b}$ & $5.29 \pm 0.02^{b}$ \\
\hline Ferulic acid & $6.29 \pm 0.03^{b}$ & $6.21 \pm 0.02^{b}$ & $4.85 \pm 0.04^{c}$ & $4.52 \pm 0.06^{c}$ \\
\hline Combination (1:1) & $6.33 \pm 0.05^{b}$ & $6.26 \pm 0.03^{b}$ & $4.97 \pm 0.04^{c}$ & $4.87 \pm 0.04^{c}$ \\
\hline \multicolumn{5}{|c|}{ L. monocytogenes (ATCC 7644) } \\
\hline Control & $7.87 \pm 0.03^{\mathrm{a}}$ & $8.08 \pm 0.05^{\mathrm{a}}$ & $8.17 \pm 0.04^{\mathrm{a}}$ & $8.21 \pm 0.03^{a}$ \\
\hline Caffeic acid & $6.19 \pm 0.02^{b}$ & $6.01 \pm 0.03^{b}$ & $5.92 \pm 0.06^{b}$ & $5.86 \pm 0.08^{b}$ \\
\hline Ferulic acid & $6.24 \pm 0.03^{b}$ & $6.09 \pm 0.03^{b}$ & $6.03 \pm 0.05^{b}$ & $6.01 \pm 0.02^{b}$ \\
\hline Combination (1:1) & $6.22 \pm 0.02^{b}$ & $6.05 \pm 0.03^{b}$ & $6.01 \pm 0.04^{b}$ & $5.96 \pm 0.03^{b}$ \\
\hline
\end{tabular}

Superscripts indicate significant differences $(P<0.05)$ across the columns only for each phenolic acid used.

$7.51 \times 10^{8}$ to $7.96 \times 10^{8} \mathrm{CFU} / \mathrm{mL}$ for $L$. monocytogenes. At a concentration of $150 \mathrm{ppm}$, the combination of caffeic acid and ferulic acid was found to be most effective against E. coli $\mathrm{O} 157: \mathrm{H} 7$ in comparison to caffeic acid, and ferulic acid was applied individually, with a log reduction of $3.38 \mathrm{CFU} / \mathrm{mL}$ at $72 \mathrm{~h}$. As observed in broth media, caffeic acid revealed the greatest effects against $L$. monocytogenes in cold-cut meats with a log reduction of 2.44 CFU/ $\mathrm{mL}$ at the maximum incubation period. At a concentration of $200 \mathrm{ppm}$, a similar pattern of effectiveness was documented for both Gram-positive and Gram-negative strains, with a higher inhibition rate (Table 3 ). The survival rate was lower for both strains, indicating that the synergistic effect of the combination of caffeic acid and ferulic acid was more effective in the meat compared to the broth. This could be attributed to the presence of macromolecules (proteins, lipids) and micromolecules (vitamins) in the food matrix (meat), which provided enhanced affinity for phenolic compounds. Arima et al. (2002) reported that the combinations of quercetin and quercitrin, quercetin and morin, and quercetin and rutin portrayed synergistic effects resulting in improved efficacy than individual flavonoids against Bacillus cereus and Salmonella enteritidis.
The inhibitory effect of phenolic compound mixtures was greater at $4^{\circ} \mathrm{C}$ incubation temperature than at $20^{\circ} \mathrm{C}$ for meat (Rodriguez-Vaquero et al., 2011) and fish (Rodríguez-Vaquero et al., 2013), reducing the viability of L. monocytogenes at two concentrations (100 and $200 \mathrm{mg} / \mathrm{L}$ ). This is because their mode of action depends on their migration into bacterial membranes, which reduce fluidity at lower temperatures (Ultee et al., 2000). Beuchat et al. (1994) substantiated the improved antibacterial effect of phenolic compounds at low storage conditions. The shelf lives of foods could be further preserved by hurdle technology, such as in the case of combining refrigeration temperatures between $0^{\circ} \mathrm{C}$ and $4^{\circ} \mathrm{C}$ with modified atmosphere packaging to preserve foods (Leistner \& Gorris, 1995).

\section{Conclusions}

Caffeic acid, ferulic acid, and their combination have potentials for the effective reduction or inhibition of foodborne pathogens; thus, providing a good alternative to chemical additives. Zones of inhibition of E. coli and L. monocytogenes were widened with an increase in the 
Table 3 The effect of phenolic compounds (at $150 \mathrm{ppm}$ ) against $E$. coli 0157:H7 and L. monocytogenes at $4^{\circ} \mathrm{C}$ for over $72 \mathrm{~h}$ in meat.

\begin{tabular}{|c|c|c|c|c|}
\hline \multirow[t]{2}{*}{ Phenolic acids (150 ppm) } & \multicolumn{4}{|c|}{ Population (log CFU/g) over storage period (h) of } \\
\hline & 12 & 24 & 48 & 72 \\
\hline \multicolumn{5}{|c|}{ E. coli 0157:H7 (ATCC 43888) } \\
\hline Control & $7.49 \pm 0.06^{a}$ & $7.70 \pm 0.05^{\mathrm{a}}$ & $7.76 \pm 0.06^{a}$ & $7.75 \pm 0.11^{a}$ \\
\hline Caffeic acid & $5.67 \pm 0.04^{b}$ & $5.51 \pm 0.04^{b}$ & $5.22 \pm 0.05^{b}$ & $4.98 \pm 0.05^{b}$ \\
\hline Ferulic acid & $5.49 \pm 0.02^{c}$ & $5.31 \pm 0.04^{c}$ & $5.06 \pm 0.08^{b}$ & $4.51 \pm 0.11^{b}$ \\
\hline Combination (1:1) & $5.42 \pm 0.03^{c}$ & $5.21 \pm 0.04^{c}$ & $4.91 \pm 0.02^{b}$ & $4.37 \pm 0.04^{c}$ \\
\hline \multicolumn{5}{|c|}{ L. monocytogenes (ATCC 7644) } \\
\hline Control & $7.51 \pm 0.05^{\mathrm{a}}$ & $7.71 \pm 0.05^{\mathrm{a}}$ & $7.87 \pm 0.04^{\mathrm{a}}$ & $7.96 \pm 0.02^{\mathrm{a}}$ \\
\hline Caffeic acid & $6.29 \pm 0.02^{c}$ & $6.09 \pm 0.03^{b}$ & $5.76 \pm 0.03^{b}$ & $5.52 \pm 0.04^{b}$ \\
\hline Ferulic acid & $6.52 \pm 0.02^{b}$ & $6.39 \pm 0.02^{b}$ & $6.12 \pm 0.03^{b}$ & $5.97 \pm 0.06^{b}$ \\
\hline Combination (1:1) & $6.41 \pm 0.03^{c}$ & $6.27 \pm 0.08^{b}$ & $5.99 \pm 0.03^{b}$ & $5.68 \pm 0.04^{b}$ \\
\hline \multicolumn{5}{|c|}{$\begin{array}{l}\text { Phenolic acids (200 ppm) } \\
\text { E. coli 0157:H7 (ATCC 43888) }\end{array}$} \\
\hline Control & $7.49 \pm 0.06^{a}$ & $7.70 \pm 0.05^{\mathrm{a}}$ & $7.76 \pm 0.06^{a}$ & $7.75 \pm 0.11^{a}$ \\
\hline Caffeic acid & $5.34 \pm 0.08^{b}$ & $5.21 \pm 0.05^{b}$ & $4.94 \pm 0.07^{b}$ & $4.67 \pm 0.08^{b}$ \\
\hline Ferulic acid & $5.24 \pm 0.05^{b}$ & $5.10 \pm 0.02^{b}$ & $4.76 \pm 0.08^{b}$ & $4.23 \pm 0.04^{c}$ \\
\hline Combination (1:1) & $5.19 \pm 0.02^{b}$ & $5.07 \pm 0.06^{b}$ & $4.66 \pm 0.08^{b}$ & $4.09 \pm 0.02^{c}$ \\
\hline \multicolumn{5}{|c|}{ L. monocytogenes (ATCC 7644) } \\
\hline Control & $7.51 \pm 0.05^{\mathrm{a}}$ & $7.71 \pm 0.05^{\mathrm{a}}$ & $7.87 \pm 0.04^{\mathrm{a}}$ & $7.96 \pm 0.02^{\mathrm{a}}$ \\
\hline Caffeic acid & $6.02 \pm 0.04^{b}$ & $5.63 \pm 0.02^{b}$ & $5.52 \pm 0.05^{b}$ & $5.25 \pm 0.02^{c}$ \\
\hline Ferulic acid & $6.19 \pm 0.02^{b}$ & $5.77 \pm 0.04^{b}$ & $5.74 \pm 0.04^{b}$ & $5.63 \pm 0.04^{b}$ \\
\hline Combination (1:1) & $6.12 \pm 0.03^{b}$ & $5.77 \pm 0.04^{b}$ & $5.68 \pm 0.03^{b}$ & $5.49 \pm 0.02^{c}$ \\
\hline
\end{tabular}

Superscripts indicate significant differences $(P<0.05)$ across the columns only for each phenolic acid used.

concentration of phenolic acids, with ferulic acid having the greatest inhibition effect on E. coli at $200 \mathrm{ppm}$. For the two concentrations tested, phenolic acids were more efficacious against $E$. coli in broth and meat as the storage hours increased, compared to L. monocytogenes. However, the greater effects were obtained at $200 \mathrm{ppm}$ for the two phenolic acids and their combination for both microorganisms. These results show the effectiveness of phenolic acids tested, at the stipulated concentrations, against the pathogenic organisms investigated and, as such, may allow the formulation of new antimicrobial products for potential use as food preservatives. Further studies involving sensory evaluation may be necessary to determine consumer acceptability of caffeic and ferulic acid-treated meats.

\section{Acknowledgments}

This work is based on research supported in part by the National Research Foundation of South Africa, SA (NRF)/Russia (RFBR) Joint Science and Technology Research Collaboration (Grant Number: 118910).

\section{References}

Arima, H., Ashida, H. and Danno, G.I., 2002. Rutin-enhanced antibacterial activities of flavonoids against Bacillus cereus and Salmonella enteritidis. Bioscience, Biotechnology, and Biochemistry 66(5):1009-1014. https://doi.org/10.1271/bbb.66.1009

Beuchat, L.R., Brackett, R.E. and Doyle, M.P., 1994. Lethality of carrot juice to Listeria monocytogenes as affected by $\mathrm{pH}$, sodium chloride and temperature. Journal of Food Protection 57(6): 470-474. https://doi.org/10.4315/0362-028X-57.6.470

Buchanan, R.L., Gorris, L.G., Hayman, M.M., Jackson, T.C., and Whiting, R.C., 2017. A review of Listeria monocytogenes: an update on outbreaks, virulence, dose-response, ecology, and risk assessments. Food Control 75:1-13. https://doi.org/10.1016/j. foodcont.2016.12.016

Campion, A., Morrissey, R., Field, D., Cotter, P.D., Hill, C., and Ross, R.P., 2017. Use of enhanced nisin derivatives in combination with food-grade oils or citric acid to control Cronobacter sakazakii and Escherichia coli O157: H7. Food Microbiology 65: 254-263. https://doi.org/10.1016/j.fm.2017.01.020

Chen, J.Q., Regan, P., Laksanalamai, P., Healey, S., and Hu, Z., 2017. Prevalence and methodologies for detection, characterization and subtyping of Listeria monocytogenes and 
L. ivanovii in foods and environmental sources. Food Science and Human Wellness 6(3):97-120. https://doi.org/10.1016/j. fshw.2017.06.002

Cheynier, V., 2012. Phenolic compounds: from plants to foods. Phytochemistry Reviews 11:153-177. https://doi.org/10.1007/ s11101-012-9242-8

De Souza, J., Ahmed, R., Strange, P., Barbut, S. and Balamurugan, S., 2018. Effect of caliber size and fat level on the inactivation of E. coli O157: $\mathrm{H} 7$ in dry fermented sausages. International Journal of Food Microbiology 266:167-172. https://doi.org/10.1016/j. ijfoodmicro.2017.11.024

Hunjak, B., Andric, N., Beslic, I. and Fabris, A., 2019. Listeria monocytogenes - clinical significance in pregnant women and newborns. International Journal of Infectious Diseases 79:88. https://doi.org/10.1016/j.ijid.2018.11.221

Kwon, S.A., Song, W.J. and Kang, D.H., 2019. Combination effect of saturated or superheated steam and lactic acid on the inactivation of Escherichia coli O157: H7, Salmonella typhimurium and Listeria monocytogenes on cantaloupe surfaces. Food Microbiology 82:342-348. https://doi.org/10.1016/j. fm.2019.03.012

Leistner, L. and Gorris, L.G., 1995. Food preservation by hurdle technology. Trends in Food Science and Technology 6(2):41-46. https://doi.org/10.1016/S0924-2244(00)88941-4.

Marušić, N., Vidaček, S., Janči, T., Petrak, T. and Medić, H., 2014. Determination of volatile compounds and quality parameters of traditional Istrian dry-cured ham. Meat Science 96(4):1409_ 1416. https://doi.org/10.1016/j.meatsci.2013.12.003

Maurya, D.K. and Devasagayam, T.P.A., 2010. Antioxidant and prooxidant nature of hydroxycinnamic acid derivatives ferulic and caffeic acids. Food and Chemical Toxicology 48(12):3369-3373. https://doi.org/10.1016/j.fct.2010.09.006

Nyström, L., Mäkinen, M., Lampi, A.M. and Piironen, V., 2005. Antioxidant activity of steryl ferulate extracts from rye and wheat bran. Journal of Agricultural and Food Chemistry 53(7):25032510. https://doi.org/10.1021/jf048051t

Pernin, A., Dubois-Brissonnet, F., Roux, S., Masson, M., Bosc, V. and Maillard, M.N., 2018. Phenolic compounds can delay the oxidation of polyunsaturated fatty acids and the growth of Listeria monocytogenes: structure-activity relationships. Journal of the Science of Food and Agriculture 98(14):5401-5408. https://doi. org/10.1002/jsfa.9082

Pernin, A., Guillier, L. and Dubois-Brissonnet, F., 2019. Inhibitory activity of phenolic acids against Listeria monocytogenes: deciphering the mechanisms of action using three different models. Food Microbiology 80:18-24. https://doi.org/10.1016/j. fm.2018.12.010
Rodriguez-Vaquero, M.R., Alberto, M.R. and de Nadra, M.M., 2007. Antibacterial effect of phenolic compounds from different wines. Food Control 18(2):93-101. https://doi.org/10.1016/j. foodcont.2005.08.010

Rodriguez-Vaquero, M.J., Aredes Fernández, P.A. and Manca de Nadra, M.C., 2011. Effect of phenolic compound mixtures on the viability of Listeria monocytogenes in meat model. Food Technology and Biotechnology 49(1):83-88.

Rodríguez-Vaquero, M.J., Aredes Aredes-Fernández, P. and Manca de Nadra, M.C., 2013. Phenolic compounds from wine as natural preservatives of fish meat. Food Technology and Biotechnology 51(3):376-382.

Romaniuk, J.A. and Cegelski, L., 2015. Bacterial cell wall composition and the influence of antibiotics by cell-wall and whole-cell NMR. Philosophical Transactions of the Royal Society B: Biological Sciences 370(1679):20150024. https://doi. org/10.1098/rstb.2015.0024

Rybarczyk, J., Kieckens, E., Vanrompay, D. and Cox, E., 2017. In vitro and in vivo studies on the antimicrobial effect of lactoferrin against Escherichia coli O157: H7. Veterinary Microbiology 202:23-28. https://doi.org/10.1016/j.vetmic.2016.05.010

Sánchez-Maldonado, A.F., Schieber, A. and Gänzle, M.G., 2011. Structure-function relationships of the antibacterial activity of phenolic acids and their metabolism by lactic acid bacteria. Journal of Applied Microbiology 111(5):1176-1184. https:// doi.org/10.1111/j.1365-2672.2011.05141.x

Saxena, T., Kaushik, P. and Mohan, M.K., 2015. Prevalence of E. coli O157: H7 in water sources: an overview on associated diseases, outbreaks and detection methods. Diagnostic Microbiology and Infectious Disease 82(3):249-264. https://doi.org/10.1016/j. diagmicrobio.2015.03.015

Shpaizer, A., Nussinovich, A., Kanner, J. and Tirosh, O., 2018. $\mathrm{S}$-nitroso-N-acetylcysteine generates less carcinogenic $\mathrm{N}$-nitrosamines in meat products than nitrite. Journal of Agricultural and Food Chemistry 66(43):11459-11467. https:// doi.org/10.1021/acs.jafc.8b04549

Ultee, A., Slump, R.A., Steging, G. and Smid, E.J., 2000. Antimicrobial activity of carvacrol toward Bacillus cereus on rice. Journal of Food Protection 63(5):620-624. https://doi. org/10.4315/0362-028X-63.5.620

Zhang, H., Wu, J. and Guo, X., 2016. Effects of antimicrobial and antioxidant activities of spice extracts on raw chicken meat quality. Food Science and Human Wellness 5(1):39-48. https://doi. org/10.1016/j.fshw.2015.11.003 